\title{
Aydın Adnan Menderes Üniversitesi Tıp Fakültesi'nde Pandemi Döneminde Eğitim
}

\section{Education During the Pandemic in Aydın Adnan Menderes University Faculty of Medicine}

\author{
Selcen Öncü * (ORCID: 0000-0001-6329-4227)
}

* Aydın Adnan Menderes Üniversitesi Tıp Fakültesi. Aydın, Türkiye.

Sorumlu Yazar: Selcen Öncü, E-Posta: selcenoncu@hotmail.com

\section{Özet}

Aralık 2019 sonunda Çin'de ortaya çıkarak kısa sürede tüm dünyayı etkileyen bir pandemiye dönüşen Koronavirüs (Covid-19) küresel çapta bir krize neden olarak yaşamın pek çok alanında etkisini göstermiştir. Virüsün damlacık yolu ile bulaşması, pandeminin hızla ilerlemesi ve ölümcül olması nedeni ile çok sayıda ülkede sosyal mesafenin korunması ve yayılımın kısıtlanması amacı ile yüz yüze eğitime ara verilmiştir. Bu ülkelerden biri olan ülkemizde üniversitelerde yüz yüze eğitime ara verilmesi ile 23 Mart 2020 tarihinden itibaren eğitimin aksamaması için uzaktan eğitime geçilmesine karar verilmiştir. Üniversitemiz Aydın Adnan Menderes Üniversitesi bu kararı takiben mevcut uzaktan eğitim sisteminde gerekli düzenlemeleri yaparak 30 Mart 2020 tarihinde uzaktan eğitime başlamıştır. Fakültemizde ise uzaktan eğitim süreci eğitim programının uzaktan eğitime

\section{Anahtar sözcükler:}

Koronavirüs pandemisi,

Tıp fakültesi, Uzaktan eğitim

\section{Keywords:}

Coronavirus pandemic, Medical school, Distance education

Gönderilme Tarihi

Submitted:15.09.2020

Kabul Tarihi

Accepted: 21.10.2020 uygun hale getirilmesi, öğrenci ve öğretim üyelerinin bilgilendirilmeleri ile 6 Nisan 2020 tarihinde başlamıştır. Bu yazıda Aydın Adnan Menderes Üniversitesi Tıp Fakültesi'nin pandemi dönemi uzaktan eğitim deneyimi aktarılmıştır.

\section{Abstract:}

Coronavirus (Covid-19), which emerged in China at the end of December 2019 and turned into a pandemic that affected the whole world in a short time, caused a global crisis and showed its effects in many areas of life. Face-to-face education has been suspended in many countries in order to maintain social distance and limit its spread due to the transmission of the virus by droplets, the rapid progress of the pandemic and its fatality. In our country, which is one of these countries, it has been decided to switch to distance education as of March 23, 2020, with a suspension of face-to-face education at universities. Following this decision, our university Aydin Adnan Menderes University started distance education on March 30, 2020 by making the necessary arrangements in the existing distance education system. In our faculty, the distance education process started on April 6, 2020 with the adaptation of the education program to distance education and informing the students and faculty members. In this article, distance education experience of Aydin Adnan Menderes University Faculty of Medicine during the pandemic period was explained.

Künye: Oncu S. Aydın Adnan Menderes Üniversitesi Tıp Fakültesi’nde Pandemi Döneminde Eğitim. 


\section{Giriș}

Aralık 2019'da Çin'in bildirdiği yeni tip Koronavirüs enfeksiyonu kısa sürede tüm dünyaya yayılıp ölümlere neden olarak 11 Mart 2020'de Dünya Sağlık Örgütü tarafindan pandemi olarak ilan edilmiştir. Yaşamın pek çok alanında etkisini gösteren pandemiden en fazla etkilenenlerden birisi de eğitim olmuştur. Dünya genelinde 17 Nisan 2020 tarihi itibariyle, 191 ülkede okulların kapatıldığı ve 1.724.657.870 öğrencinin bu süreçten etkilendiği bildirilmiştir $(1,2)$. Ülkemizde de Yükseköğretim Kurulu (YÖK), öğrencilerin eğitimlerinin aksamaması amac1 6 Mart 2020 tarihli kararında, üniversitelerde 23 Mart 2020 tarihinden itibaren eğitime uzaktan devam edilmesine karar vermiştir (3). Üniversitemiz de bu kararı takiben 30 Mart 2020 tarihinde uzaktan eğitime başlamıştır. $\mathrm{Bu}$ yazıda fakültemizin pandemi sürecindeki uzaktan eğitim deneyimi aktarılmıştır.

\section{Genel Bilgiler}

Aydın Adnan Menderes Üniversitesi'nde (ADÜ) eğiticilerin 23 Mart'tan itibaren bir hafta içerik geliştirip sisteme yüklemeleri ile 30 Mart'ta uzaktan eğitim dersleri başlamıştır. Uzaktan eğitim; Şubat 2020'de uzaktan eğitim verme onayı almış olan ADÜ Uzaktan Eğitim Sistemi (ADÜZEM) kullanılarak gerçekleştirilmiştir. ADÜZEM bu süreci "evdekal.adu.edu.tr" web adresiyle yürütmüştür. Portal içerisinde yol gösterici videoların yanında e-destek ve canlı destek için tanımlanan telefon hattından ise yaklaşık 100 kişilik bir ekip 08.00-23.00 saatleri arasında hizmet vermiştir. ADÜZEM portal, fakülte ve bölümlere ait uzaktan eğitim ve sinav hizmeti için Öğrenci Bilgi Sistemi (OBİS) ile birlikte çalışmaktadır. Tıp fakültesinde ise farklı eğitim sistemi ve işleyiş nedeniyle, ADÜZEM ve fakültemiz lisanslı yazılımı Tıp Öğrenci Bilgi Portalı (TIPPORTC) ile uyumlu çalışmaktadır. Fakültemizde uzaktan eğitim Dönem I, II, III senkronize (etkileşimli) teorik dersleri ile 6 Nisan 2020, dönem IV ve V için 27 Nisan 2020 tarihinde başlamış olup, senkronize dersler, ekran paylaşımlı konu anlatımları ile desteklenmiştir. Senkronize derslerin kayd 1 yapılıp sisteme yüklenerek öğrencilerin asenkron olarak da ders videolarına erişimi sağlanmıştır. Başlarda, uygulamaların ve klinik eğitimin yüz yüze verilmesi planlanmış, ancak pandeminin ilerleyişinden dolayı YÖK tarafindan alınan yeni kararlar nedeniyle planlamaları yapılarak uygulama dersleri de uzaktan eğitim sürecine dâhil edilmiştir.

Covid-19 salgını sürecinde Fakülteniz eğitim programında yapılan değişiklikler ve eğitimin yürütülmesi sürecinde yaşananlar: Uzaktan eğitim, Eğitimden Sorumlu Dekan Yardımcısı koordinatörlüğünde, Tıp Eğitimi Anabilim Dalı ve Eğitim Koordinatörlüğü'nün yürütücülüğünde gerçekleştirilmiştir. Eğitimin planlanması ve değiş̧ikliklerde Eğitimden Sorumlu Dekan Yardımcısı, Tıp Eğitimi Anabilim Dalı temsilcisi, dönem koordinatör ve yardımcıları ile fakülte öğrenci temsilcisinin yer aldığ1 Tip Eğitini Koordinasyon Kurulu (TEKOK) ve Eğitim Koordinatörlüğü birlikte çalışmış, düzenli toplantılar gerçekleştirilmiştir. Ders programları uzaktan eğitimde yatay entegrasyon bozulmayacak şekilde tanımlanarak düzenlenmiştir.

$\mathrm{Bu}$ sürecin başında eğiticiler, telekonferans yolu ile bilgilendirilmiş, e-posta ve elektronik bilgi yönetim sistemi ile hazırlanan videolar ve kılavuzlar ile de bilgilendirmeler yapılmıştır. Süreçte iletişimi hızlandırmak için Whatsapp grupları oluşturulmuş, erişim ve kullanım ile ilgili sorunlar için canlı destek ve e-destek ile hizmet verilmiştir. Öğrenciler için Dekanlık tarafindan düzenli bilgilendirmeler yapılırken dönem öğrenci temsilcileri ile de telekonferans yöntemi ile toplantılar yapılarak sürece dahil edilmeleri sağlanmıştır. ADÜZEM üzerinde öğrencilerle yüz yüze etkileşimli dersler, ekran 
paylaşımlı konu anlatımları ile desteklenmiştir. Ders materyali paylaşımı için, her bir ders kurulu ve klinik eğitim için sanal sınıflar (classroom) oluşturulmuştur. Klinik dönemlerde; sanal sinıflara yüklenen videolar ve vakalar uygulama derslerinde öğrenciler ile tartışılarak senkronize dersler olarak gerçekleştirilmiş ve kaydedilmiştir. Uzaktan eğitimde firsat eşitsizliğinin oluşabileceği ve evlerine gidemeyecek öğrenciler düşünülerek uzaktan eğitimde yararlanabilmeleri için gerekli önlemler alınarak öğrenci bilgisayar laboratuvarı öğrencilerin kullanımına açık bulundurulmuştur. Uzaktan eğitim sürecinin verimli olarak gerçekleştirilmesi için yeterli sayıda derslik gerekli donanım sağlanarak eğiticilerin kullanımına sunulmuştur.

Fakültemizde 6 Nisanda başlayan uzaktan eğitim teorik dersleri 22 Mayıs, uygulama dersleri 18 Haziran'da tamamlanmıştır. Bu süreçte 234 eğitici ders vermiş, 1246 öğrenci derslere katılmıştır, uzaktan eğitim sürecinde sisteme kaydedilen dijital ders materyali 945, materyallerin toplam indirilme sayıs1 75.823 , gerçekleştirilen etkileşimli ders oturum sayısı 1183 ve asenkronize ders sayısı 1109 olarak belirlenmiştir.

Uzaktan eğitim sürecinde üniversitemiz eğitimin değerlendirilmesinde ödev, proje, online sınav gibi seçenekler sunmuş, fakültemiz online sınavı tercih etmiştir. ADÜZEM sınav portalında tablo/resim ekleme özelliğinin olmaması, öğrencinin soru kitapçı̆̆ının tamamını görememesi ve önceki soruya geri dönememesi nedenlerinden dolayı alternatif bir sinav sistemi arayışına gidilmiştir.

Eğitim

Koordinatörlüğünün desteği ile sinavların Google Forms kullanarak ADÜZEM üzerinden yürütülmesi sağlanmıştır. Sınavlar, eğiticilerin Fakültemiz lisanslı yazılımı SoruBankası(C) üzerinden girdiği soruların Google Forms'a aktarılması ile gerçekleştirilmiştir. 8 Haziran-24 Temmuz 2020 arasinda toplam 6.500 adet sorunun kullanıldığ 124 adet online sinav gerçekleştirilmiştir.

Dönem I-V'de uzaktan eğitim devam ederken YÖK'ün 24.04.2020 tarihli kararı ile intörn hekimlerin mezuniyetlerinin gecikmesinin önlenmesi adına sunulan seçenekler intörn hekimlerimize sunularak isteklerini belirtmeleri istenmiştir. İntörn hekimlerin çoğu eğitimlerinin kalan süresini yüz yüze yapmak istediklerini belirtmiştir. Gönüllü olanların eğitimlerinin kalan süreleri rızaları alınarak üniversite hastanesinde yoğunlaştırılmış olarak ve bir kısmı da uzaktan eğitim ile senkronize dersler, ödev ve vaka tartışması gibi etkinlikler ile tamamlanmıştır (4).

Eğitim programında ulaşılamadığı düşünülen hedefler ve 2020-2021 döneminde bu eksiklikler için alınan önlemler: Eğitim programında ulaşılamadığı düşünülen hedefler özellikle klinik dönemde olan Dönem IV ve Dönem V için teorik dersler ve klinik uygulamaların uzaktan verildiği klinik eğitimler için beceri ve tutum hedefleri olabilir. Bu eksikliğin telafisi için öğrencilerin alamadığ1 klinik eğitimleri 2020-2021 döneminde yoğunlaştırılmış seçmeli stajlar olarak alabilme olanağı tanınmıştır. Hasta başı tartışmalar sanal sınıflarda etkileşimli olarak olgu tartışmaları şeklinde gerçekleştirilerek hekim adaylarının hasta yaklaşımları ve problem çözme becerileri geliştirilmeye çalışılmış, bu yöntemin ayrıca klinik beceriler ve cerrahi teknikler için de kullanılabileceği düşünülmüştür (5).

Yaşanan salgın sürecinin Fakültemizde kalıcı olduğunu düşündüğümüz etkileri ve nedenleri: Fakültemiz salgin sürecinde ADUZEM alt yapısının da uygun olması nedeni ile kısa sürede uzaktan eğitime başlayabilmiş ve dersleri senkronize olarak gerçekleştirebilmiştir. Bu kriz ve kaos sürecinin başarıyla atlatılmış olması çok büyük önem taşısa da öğrencilerin özellikle beceri hedeflerinde istenilen düzeye ulaşamamış olma kaygısı taşınmaktadır. Ayrıca uzaktan 
eğitim iyi koşullarda gerçekleştirilmiş olsa da klinik eğitimde bilgi, beceri ve tutumu birlikte kazandırabilen, geleneksel usta çırak ilişkisinin ve rol modelliğin de önem taşıdığı bir eğitimdir ve beklenen hedeflere tam olarak ulaşılamayacağı kaygısını taşımaktayız.

Fakültemizde salgın sürecinde Tıp Eğitimi Anabilim Dalının, eğitim yönetiminin ve diğer paydaşların rolü ve etkileri: Uzaktan eğitimin planlanması ve yürütülmesi sürecinde Fakültemiz Eğitim Koordinatörlüğü ADÜZEM ile ortak çalışmıştır. Salgın sürecinde eğitim ile ilgili alınacak tüm kararlar öncelikle öğrenci görüşlerini alan ve onları temsil eden dönem (IVI) öğrenci temsilcileri ile tartışılmıştır. Sonrasında eğitimden sorumlu Dekan Yardımcısı, Tıp Eğitimi Anabilim Dalı temsilcisi, dönem koordinatörleri ve yardımcılarından oluşan Tıp Eğitimi Koordinasyon Kurulu'nda (TEKOK) görüşülerek Fakülte Kurulu'na sunulmuş, Fakülte Kurulunda onaylandıktan sonra Üniversite Senatosunda da görülerek uygulamaya konulmuştur.

Diğer fakülteler ve ilgili kurumlarla işbirlikleri ve katkılar ve diğer konularda değerlendirmeler: Belirsizliğin çok fazla olduğu, planlanan programların uygulanamadığı bu olağanüstü süreçte klinik ve intörn eğitimleri ile ilgili olarak hastane pandemi ekibinin görüşü alınarak hastane yönetimi ile işbirliği içinde olunmuştur. Toplum tabanlı eğitimler için İl Sağlık Müdürlüğü ile iletişim korunmuştur. Bölgemizdeki diğer tıp fakülteleri ile bağlantı kurularak görüşleri ve uygulama örnekleri ile ilgili karşı1ıklı fikir alışverişleri yapılmıştır. Tüm bunların yanında TEPDAD önerileri dikkate alınmış ve yol gösterici olmuştur. Ayrıca, uzaktan eğitim sürecinin başından itibaren planlamalarda YÖK Kararları esas alınmıştır. Tüm bu işbirlikleri sürdürülürken durumun belirsizliği planlamalarda gecikmelere ve değişikliklere neden olmuştur.

\section{Sonuç}

Kovid pandemisi ile hızlı bir geçiş yapılan uzaktan eğitim fakültemiz için ciddi bir deneyim olmuştur. Tip eğitiminin doğası gereği iyi hekim yetiştirebilmek için klinikler ve hasta baş1 deneyimler zaruri olsa da uzaktan eğitim deneyimimizin bizlere öğrettikleri ile uzaktan eğitim ve farklı teknolojilerin kullanımının eğitim programımızın farklı dönemlerine entegre edilmesinin eğitimimizi zenginleştireceği düşüncesindeyiz.

\section{Kaynaklar}

1. UNESCO (2020a). COVID-19 educational disruption and response. https://en.unesco.org/covid19/educationrespons e, Erişim tarihi: 17.04.2020.

2. Telli Yamamoto G, Altun D. Coronavirüs ve Çevrimiçi (Online) Eğitimin Önlenemeyen Yükselişi. Üniversite Araştırmaları Dergisi, Nisan 2020, Cilt 3, Say1 1, Sayfa: 25-34

3. https://covid19.yok.gov.tr/alinan-kararlar, "YÖK'ten Koronavirüs (COVID-19) Hakkında Yükseköğretim Kurumlarında Alınacak Tedbirlere İlişkin Öneriler", Erişim tarihi: 01.06.2020

4. https://covid19.yok.gov.tr/alinan-kararlar, "YÖK'ten Salgın Sürecinde Doktor Adaylarının Mezuniyetlerini Kolaylaştıracak Yeni Karar", Erişim tarihi: 01.06.2020

5.Kim S. The future of e-Learning in medical education: Current trend and future opportunity. J Educ Eval Health Prof. 2006;3:3. 